\title{
建築紛争解決型専門家集団としてのまちづくり NPO MACHIDUKURI-NPOS AS PROFESSIONAL ORGANIZATION SOLVING THE ARCHITECTURAL CONFLICTS
}

澤村 明*

Akira SA WAMURA

\begin{abstract}
Some NPOs try to act as professional organizations solving the architectural conflicts. In this paper, I try to confirm the difinition of 'Machidukuri' (community development) at first, then examine 2 cases, and discuss the future of such NPOs. As conclusion, I suggest that NPOs have advantage to professional persons on merits as institution, but also NPOs have some problems to be solved that they have to brush up their professional knowledge always, or have the balanced perspective of not amateurism nor excessive professionalism.
\end{abstract}

Keywords: NPO, Machidukuri, Community Development, Architectural Conflict, Professional $\mathrm{NPO}$ 、まちづくり、建築紛争、専門家

はじめに

1995 年の阪神・淡路大震災を契機に日本でも認知されるように なったN P O（民間非営利組織）も、1998年の通称 N P O法、特定 非営利活動促進法の成立、同年 12 月の施行後、同法によって認証さ れた特定非営利活動法人の数は 2002 年 7 月現在で 7 千 6 百を超え ている。

N P O 法では法人の活動内容として12分野を列挙する中に「まち づくり」も挙げられており!まちづくりにおいてN P Oが一定の 役割を果たすことを前提としているといってよいだろう。当然なが ら、法制定以前から存在していた「まちづくり N P O」の活動の成 果でもあるが、N P O法によって正式に市民権をえた「まちづくり NPO」が今後、質量ともに大きくなっていくことが予想できる。

しかしながら、既に 7 千を超えた特定非営利活動法人を含むN P ○を概括すると、そこで標榜される「まちづくり」という概念には、 整理が必要である。本論では、「まちづくりN P O」を規定しなお すとともに、近年激化している建築紛争の解決を目指す専門家集団 としての「まちづくり N PO」について考察する。建築紛争に関し ては、ここ数年の規制緩和により近隣紛争と欠陉建築問題とも增加 傾向にあり2、建築学会でも裁判所の要請を受け、民事調停や鑑定 に学会として協力するための「建築紛争支援会議」を2000年 12 月 から始めている。これは中立的に専門家として意見を述べる立場で あるが、一方の当事者である被害者（あるいは近隣住民）側に立っ て専門的見地から助言などを N P Oが行うケースも見られ、本論で はそうした動きについて論じる。

\section{1．本論で取り上げるNPOの範囲}

日本でN P Oが認知されるようになったのは1995年の阪神・淡路 大震災での N P O やボランティアの活動が契機であるが、98 年の通 称 N P O 法の成立までは法人設立上のエアポケットとなっていたた め、便宜的に有限会社などの法人格を取得して民間非営利活動を行っ ている「N PO」もある。それらとは別に、法人格を取得していない 「人格なき社団」いわゆる任意団体も多く、N P Oと称する団体につ いての定義が必要であろう。

N P Oについてのテキストブックなどでもはっきりと定義はでき ずও、状況に応じて使い分ける必要があるとしているが、本論では、次 のように定義する。まず、最狭義の「NPO」としては、通称 N P O 法によって法人格を与えられた特定非営利活動法人（略称「特活法 人」、「(特活)」) があるが、法人格を取得していない任意団体でもサ ラモンの定義にあてはまるものを含めて「狭義のN P O」とする4。以 下の文中で特に断らないかぎり、この範囲を N P O 記す。これらに 加えて、公益法人等と5、法制度上の不備から便宜的に有限会社・株 式会社、協同組合などの営利法人格を取得しているが、定款などで配 当を禁止し公益的活動を行っている団体を含めて、「広義のN P O」 とする。さらに、配当の有無は明記しないが実質的に配当もなく、活 動が公益志向であるような営利法人、組合について触れる必要がある ときは「NPO的」と冠することにする。

たとえば「まちづくり N PO」(これについて次節で定義するが) と して取り上げられることのある滋賀県長浜市の株式会社黒壁は、現在 
は「広義のN PO」といえるが、株式上場の準備を行っており、上 場がなされれば「N P O 的」団体ということは可能でも N P O と見 なすことはできない。

数量的にいうと、狭義の N P Oは、特活法人数が 2002 年 7 月現 在で7,634、それらと任意団体を併せて行政側が把握している数で 8 万 7 千弱、公益法人等が約 25 万 3 千法人である。。有限会社など まで含めた「広義のN P O」数は不明である。

\section{2.「まちづくり」「まちづくりN P O」の定義}

次にやや長くなるが、「まちづくり」についても定義しなおした い。

「まちづくり」という用語は、特に居住環境などの物理的世界、英 語でいうBuilt Environmentの改良という意味で使われるほか、地域 的な活動全般に広く使われ、その定義は今一つ明確ではない。

その系譜については、渡辺俊一他などの調查があるが7、それら は都市計画的見地から評価している嫌いがある。事典による定義で は「地域住民が共同して、あるいは地方自治体と協力して、自らが 住み、生活している場を、地域にあった住みよい魅力あるものにし ていく諸活動」とするものがありィ、都市計画的な領域に留まらな いことを意味している。

ただし、「まちづくり」といったときに、都市計画的あるいは建 設行政·建設業的な分野、すなわち地域の居住環境を改良していこ うという運動を呼ぶことが多いのも事実である。そうした現実をふ まえて、建設行政・建設業的な分野を意味する場合に「狭義のまち づくり」、それら以外を含め「地域を魅力あるものにしていく諸活 動」を「広義のまちづくり」と定義して、模式図にしてみたのが図 1である。

ある地域において、既成の行政施策制度に則って行政側が行う地 域施策全体に対して、主として住民側が行う「広義のまちづくり」 がほほ対応する形になる。さらに福祉政策や環境行政、商工政策と いった個別の政策分野ごとに、ある程度の対応性を持つ住民側の運 動がある。その一つに「狭義のまちづくり」が存在する。なお、行 政側が、新たな模索として既成の制度からはみ出したものを仕掛け るさいに、それを「まちづくり」と称する例も見受けられるが、そ れも「広義のまちづくり」に含まれるといえる。

既成制度では各施策ごとに領域がはっきり区分されているのに対 し、「まちづくり」は、迷惑施設反対運動などの一時的なものでな いかぎり、テーマが厳密ではない。図1では、建設行政と「狭義の まちづくり」は一応の対応をしているが、「狭義のまちづくり」は 建設行政や建設業の領域よりも広い媖囲を指し、かつボーダーは はっきりとしたものではない。また既成の地域政策・地域行政は、 自治体の境界を超えることはありえないが、「まちづくり」はそう いう境界線にとらわれていない。

N P O 業界全体で使われている「まちづくり」の用語は、広義の まちづくりを指す場合が多い。2001 年12月末までに認証を受けた 5,680 法人のうち、35.2\%にあたる2,000法人が定款に「まちづくり」 と記載しているとされているが、その内実は吟味が必要である。筆 者が確認したところでは、1999 年 5 月末現在の経済企画庁 (当時) 公表デー夕による国および都道府県で認証されたN P Oの総数 232 法人のうち、定款に「まちづくり」等の表記を行っている団体数が

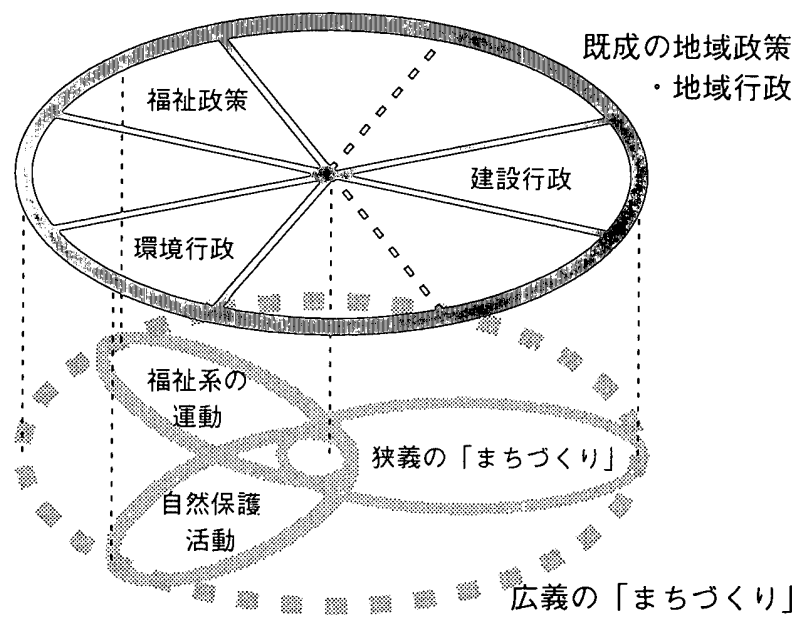

図 1 既成制度と広藏狭莪の「まちづくり」

31、そのうち狭義のまちづくりを主たる目的とすると考えられるのが 6 団体であった。たとえば（特活）ガーディアン・エンジェルスのよ うな防犯系の N P Oや福祉系のN P Oでも「安心なまちづくり」など という目的をかかげているところがあるのだが、れらは広義のまち づくりに該当する。全国のN P Oに関するデー夕を収集しているWeb サイト「N P O広場」記載のデータでは、2002 年 3 月末現在の 6,602 法人中、活動分野として「まちづくり」を挙げているのが1,263、j ち主たる活動分野が「まちづくり」であるのが279法人である。後者 の中には、同性愛者やエイズ患者のネットワークづくりや偏見啓発を 活動目的とする (特活) 動くゲイとレズビアンの会などのように、狭 義のまちづくりに含まれないものが入っている。このようにN P O 法 人全体で「まちづくり」という言葉はよく使われているものの、狭義 のまちづくり N P Oの割合は、大きなものではないといえる。

N P O 法では、注1に揭げたように、特定非営利活動の範囲がテー マ別に限定列挙されているが、そこで挙げられた12 分野は全て広義 のまちづくりに相当する。これはある意昧当然であるが、注意すべき はその12 分野の一つに「まちづくりの推淮」があることである。法 案提出までの議論の中では、「まちづくり」とは別に「住まいづくり」 もテーマの候補に挙がっていたものの、議論の経過で「まちづくりに 含まれるから」と統合されたという!。つまり、N P O 法で想定して いる「まちづくり」は、Built Environment関係、すなわち建設行政あ るいは建設業に对応する市民運動的な蓒囲のみを指すと見てよい。 もっとも、当初は狭義のまちづくりであったとしても、法案審議中に 搪大解积され、たとえばオンブズマンはまちづくりに含まれるとされ ている"。この拡大解釈は他の分野についても行われているようだ。 したがって、一般的な「まちづくり」という言葉は、広義のまちづ くりの意味合いで使われることが多い現状を認めた上で、N P Oにつ いての議論というコンテクストの中で「まちづくり N P O」という場 合には、狭義のまちづくりをミッションとするN P O 群に限定すべき であろう。以上、これまでの研究では区別されていない点であるた め、あらためて整理を行った。

\section{3. まちづくりNPOについての先行研究とその類型化}

日本でNPOあるいは民間非営利組織という存在が認知されたのは 1995 年の阪神・淡路大震災以降であるから、文献的にもこの年次以 
降のものがほとんどである。1998 年には日本N P O 学会が設立さ れ2、近年ではN P Oに関する研究も本格的に見受けられるように なった。しかし、まちづくり N P O、すなわちBuilt Environment系 のN P O に関する研究は多くなく、論文レベルでは、福川裕一・西 郷真理子以外にほとんど見当たらない13。報告レベル、たとえば日 本建築学会の支部研究会報告や大会報告では散見されるようにな り、特に大会報告の都市計画部門ではここ $2 、 3$ 年ほど、N P Oや 参加をテーマとしたセッションが開かれている。また日本都市計画 学会の学会誌である『都市計画』では1995 年にN P Oの特集号を 組んでいる。これらのほとんどは事例報告的な内容であり14、まち づくり N P Kついて全体像をつかもうとか分析しようというもの ではない。

ハウジングアンドコミュニティ財団などでは、まちづくり N P O について、N P O 法以前から調査研究が行われている15。それらの 中には、類型化の試みもいくつか見ることができる。たとえば鎌田 宣夫は、以下のように「まちづくり市民活動」を類型化している16。

1) 参加型住まいづくり

2) 集住更新

3 ) 高齢化問題

4 ) 居住問題

5 ）環境共生

6 ）防災 $\cdot$ 復興

7 ）住環境整備・改善

8 ）街並・建物再生

9) まちづくり17

10）住まい教育

すなわち、活動内容のテーマ別に類型化が行われているといってよ い。このような分類は他にもシンクタンクの調查報告などでも多く 見られる。

\section{4.まちづくりNPOの類型化と事例}

N P O研究の歴史はまだ浅いこともあり、前述のようなテーマ別 の類型化以外の分類の試みはあまり見受けられない。以下では建 築·都市計画系の専門家がかかわることが多いまちづくり N P Oに ついて、活動の性質、すなわちどのような人々によってその活動が 担われているのか、という視点から考察する。

まちづくり N P Oは、その性質から基本的に二つの指向性を持 つ。一つは地域密着性、もう一つは都市計画や建築などの専門家の 関与性である。さらに、地域性の強弱と専門家関与性の強弱という

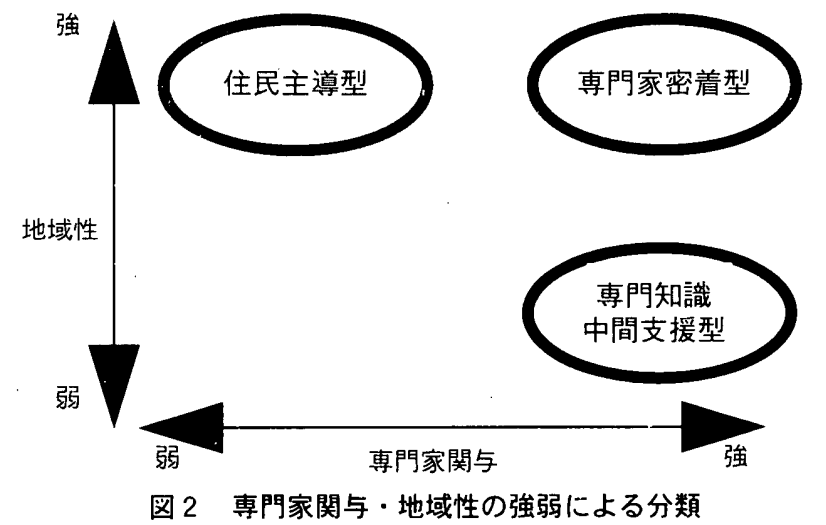

両ベクトルがあり、その高低の度合いに応じて 4 類型を考えることが できる（図 2)。地域性も専門家の関与も弱いという類型は「まちつ くり」として成り立ちにくく、ここでは考えなくてよい。ハウジング アンドコミュニティ財団の調查では、まちづくり活動に専門家が何ら かの形で加わっているものが 8 割以上であり、特に建築·都市計画系 の専門家が目立つという結果が出ている。多くの団体は地域に密着し た専門家集団であるが、その関与が強いN P Oが尃門家密着型であ る。地域密着でまちづくりを行うことを目的としながら専門家は外か ら招くという団体（住民主導型）や、逆に地域性を持たない尃門知識 中間支援型の N P O も存在する。

地域性が強く専門家の関与が低い住民主導型N P Oは本論の主たる 対象ではないが、こういうN POが尃門家を呼ぶインキュベータとし て機能することもありえよう。

もとより「まちづくり」という概念を狭義に絞ってもその内容は幅 広いことから、担い手で類型化した専門家型まちづくり N P Oに限っ ても活動範曲は広い。新潟の（特活）まちづくり学校のようにワーク ショップ指南や受託調査などを広く新潟県内で行っているところもあ れば、高崎の（特活）街・建築・文化再生集団のように、歴史的建造 物や街並みの保存活用というテーマ型の活動を行っているところもあ る。これらについての類型化も上記の例のようにさまざまに可能であ るが、本論では踏み込まない。

ここでは類型化した専門家型まちづくり N P Oの中から特に建築紛 争解決を主目的として活動している事例について取り上げる。

\section{4-1. 世田谷の欠陥住宅問題}

(特活)世田谷まちづくり市民評議会 (以下、「評議会」と略す) は、 東京都世田谷区に所在し、「地域環境における防災、社会教育、およ び住環境の保全や改善に取り組む市民を支援するために、これらに関 する事業を行い、まちづくり活動団体および行政組織や企業と新たな パートナーシップを築くことを通じて、市民主体による開かれた公共 社会を実現し、社会全体の利益の增進に寄与することを目的とする」 N P Oで、建築家や并護士が中心となって設立した。特活法人の認証 は2000年3月17日であるが、この団体の母体になったグループの活 動歴は古い。1970 年代に世田谷区内で起こったワンルームマンショ ン建設問題を受けて、近隣住民へのコンサルタント活動を開始し、そ の後は地区計画や建築協定の策定運動を行うなど、多岐にわたって長 く世田谷区内のまちづくりに携わっている。

この評議会では活動の一環として世田谷区役所の住宅相談などに協 力していたが、そうした関係から、世田谷区等々力 $5 丁$ 丁目の久陥住宅 問題に関与することになった。この欠陥住宅は、同地のいわゆる1反 開発で造成された10棟建ち並ぶ戸建て住宅が、建ぺい率·容積率才ー バーの違反建築であるだけでなく、構造その他の面について購入者が 不安を抱き、相談してきた。

このミニ開発に対し、世田谷区の建築指導部署は現場で指導を行 い、当初屋内になっていた部分の一部をべランダとさせて床面積を減 少させるなど、若干の是正は行われていた。しかし、浸水が見られる など、購入者にとっては不安が大きく、開発・建築・販売を行ったディ ベロッパーに対して何らかのアクションを起こしたいという意志が見 られたため、評議会が中心となって、法的措置を採るべく、升護士な どに連絡を取った。 
筆者らが評議会の依頼で現地を調查したところ、その欠陥ぶりが 露呈した。これらの戸建て住宅は一見したところ、R Cの擁壁で囲 まれた半地下階の上に木造 2 階建てが乗っているかのような造りで あり、地下居室の容積率緩和対象となっている。ところが、まず $\mathrm{R}$ Cの㩲壁に見えるものは合板を組んで複層吹付片を塗って R C 打ち 放しに見せ、その上に砂利を乗せて地下部に見せたハリボテであ り、さらに地下部の防水処理が不充分で降雨時には室内に浸水が見 られた。また 2 層目と 3 層目とは、地上 2 階という形でさらに小屋 毫収納を造っているのだが、小屋裏収納については当時の法規定で ある直下階の床面皘の 8 分の 1 以下という規定を守っておらず、事 実上地上 3 階建となっていた。かつ、半地下の 1 層目と事実上 4 層 目になる小屋裏を除外して 2 層目と 3 層目とを木造 2 階建てと見な して壁量計算を行ったところ、10棟全てが壁量不足であると判明し た。

筆者らの検討の結果を受け、住民の要望としては建替もしくはそ れに相当する金銭的賠償ということになった。しかし、評議会で招 聘した、欠陷建築問題に詳しい弁護士の判断では、裁判を起こした としても、既に入居後しばらく経っており、その間に居住したとい うことで相殺される利益などを差し引くと、建替に相当する金額は 望めず、建て替えるには自己負担を出さざるをえない、ということ であった。当初の要求が満たされないという予想を前に住民たちは 迷走しだす。自己負担をしてでも建て替えたいという要求を出す住 民もあれば、補強工事分を求めれば良いという意見も出、さらにい くらかでも金銭賠償が得られればやむなしという声もあり、意思統 一が図れず、訴訟にも至らない。この間、評議会では住民たちの会 合に同席してさまざまなアドバイスを行ったり、筆者らや弁護士な どの専門家との間の連絡を取り持った。

結局、住民側の意思統一は成立せず、法的行動も取れないという ことで最終的には評議会も手を引くことになり、それまでの業務に 対する報酬についても請求することはしたものの、支払われること はなかった。評議会の代表で本件を担当した小俣忠義自身も建築士 事務所を経営する建築家であり、世田谷区内で建築協定を作るなど の実績を持っている。本件でも、共同化などで従前の容積オーバー を合法的に確保できるような建替の提案を行おうとしていたが、ク ライアント側が歩調を合わせることができず適宜アドバイスしただ けで終わった。

\section{4-2. 台東区谷中のマンション問題}

東京都台東区谷中でまちづくり活動を行っている任意団体の「谷 中学校」は、まちづくり団体としては有名な存在である。東京芸術 大学出身者を中心に谷中地域に密着して活動しており、活動内容も 建築設計監理業務だけでなく、街中での芸術工芸展示などまで広義 のまちづくりに広がっている。

近年增大している建築近隣紛争で、地域住民とマンション・ディ ベロッパーの仲介役としてこの谷中学校が一役買った、「三崎坂ラ イオンズマンション」の件も知られており、インターネットの掲示 板で「マンション秎争を解決した谷中学校に連絡を取りたい」とい う書き込みがあったほどである18。谷中の寺町に地上 9 階建のマン ションを(株) 大京観光が計画したのに対して近隣住民からボ リュームの大きさに対する変更要求運動が起こった。マンションが
立地する事に対して反対するのではなく、その当初計画の 9 階建とい うボリュームに対する異議申立であった。最終的には、6階建で、さ らに道路側を 4 階建にすることでボリューム感を減じた変更案を谷中 学校が作成し、その婪を大京側が受け入れることで解決を見た。本件 は地元密着型専門家集団としての谷中学校の行動もさることながら、 地元の寺院を中心とした政治力や、台東区役所の理解と支援、さらに 大京側の判断もあって円満な解決となっている。特に、紛争の再発を 防止するために、同地域で建築協定を結はうという動きを谷中学校が 主導していることは注目に值する。

谷中地域は東京の都心であることから、大規模なマンション開発は これで終わらない。続いて1999年年末には言問通りに面した敷地に 釉合地所（株）が地上14階という大規模なマンションを計画・施工 した（施工は長谷工コーポレーション）。これに対して近隣住民の反 対が起こり、再び谷中学校が尃門家集団として運動のコンサルティン グを行うことになった。東京都の建築紛争予防条例に基づく斡旋・調 停も不調に終わり、続いて東京地裁に工事中止の仮処分申立を行う が、和解に至らず、合法な建築行為であることから工事中止が受け入 れられることもないため申立の取り下げとなっている。近隣住民が主 体となったデモ活動や抗議パフォーマンス、マスコミを巻き込んだ反 対運動も行うなど、谷中学校が主体となってさまざまに知恵を絞って

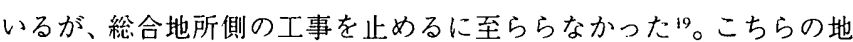
区についても、紛争の再発防止のために、なんらかの面的な協定の策 定を模索している。

高層マンションなどの建設を近隣住民の運動が阻止したり計画変更 に持ち込んだ事例は多く、なんらかの団体が関与していることも少な くないが、その多くは自治会であったり20、自治会べースの一時的な 運動団体である。その点ここの谷中学校の事例は既存の専門家集団が 関与し、着地点まで導いたというところが注目に值しょう。

\section{$4-3$. . そ他の事例}

その他、建築紛争に対応しょうというN P O 側の動きを見ることが できる。

1968 年に市民運動としてスタートした「区画整理・再開発対策全 国連絡会議」は、土地区画整理事業や市街地再開発事業の対象地域内 で事業に反対する住民に対して、反対運動や、減歩率の引き下げなど の条件闘争を指南してきた。この運動体も2000年 4 月にN P O法人 格を取得している。「いろいろな社会活動、契約関係、職員の採用な どの関係では、法人格を取得する必要を感じていた」との申で、「市 民団体として法人格を取得する場合は、やはり有限会社、株式会社と いうよりも、N P O法人が適当かと判断」したという21。

欠陥住宅問題を追求してきた明治大学の中村幸安らが設立した(特 活）建築ジーメンの会が 2000 年 8 月に認証されているように、建築 問題の解決を主なミッションとするN P O も誕生している。また東京 都調布市で都市計画マスタープランを契機にまちづくり活動を始めた 市民たちが設立した（特活）調布まちづくりの会でも、関係者たちが マンション紛争を調停するような第三者機関の可能性を検討してい る。

\section{5. 考察}

欠陥建築にせよ近隣紛争にせよ建築紛争の解決は、当事者間の任意 
交涉以外では、自治体の建築紛争予防条例にもとづく斡旋・調停に よるか、民事訴訟によることが多い。そこで問題になるのが被害者 ないし近隣住民側の立証能力である。その立証には法曹および建 築・都市計画の専門家による助言ないし作業が必要になることが多 い。この場合に専門家が非営利である必然性はないのだが、営利で 業務を行う専門家よりも非営利なスタンスのほうが有利な点を挙げ ることができる（不利な点については次章で取り上げる）。

まず、被害者が支払わなければならない費用の問題がある。無論 このような紛争では無料で無能な専門家より有料で優秀な専門家が 望ましいのであろうが、多くの場合、欠陥建築の被害者や近隣住民 には充分な資力がなく、高額な報酬を求める専門家は望みにくい。 その点では、営利目的の専門家よりも非営利の専門家のほうが分配 利潤を上乗せしない分、低額である可能性が高い。

また、N P Oについての経済学的理論では「市場の失敗」「政府 の失敗」がN P Oの存在理由とされるが22、建築紛争では、「市場の 失敗」説の中核をなす「信用」の点で、営利企業よりも N P Oのほ うが有利である。紛争解決に携わる専門家は営利企業と争うケース が多いが、敵方と同じ営利企業法人格だと支援しているはずの住民 から「同じ穴の狢」だと勘ぐられることがある。筆者が建築紛争に 携わったケースでも、「なぜあんな建物が建つのか」という近隣住 民の素朴な疑問に対して建つ理由を説明すると、「やはり建築家は 建てる側なのね」という感情的反発を受けることが多々あった。イ メージとしてNPOというと中立的に受け止められやすく、不要な 感情的対立を避けられるが、現場ではこの効用は大きい。

それ以前に、建築紛争にかかわる専門家は市民運動の発展的な意 識から身を投じるケースが多いようで、上記の事例でも取得の比較 的容易な有限会社などの営利法人格でなくN P O 法人格を取得した 理由として「市民団体としてふさわしい」「信用と中立性にくわえ、 1)何らかの法人にすることで、相談者から報酬を得られ易くするこ と、2)株式、有限のように資本金が必要無い、3)財務の透明性が高 いなど、金に関する問題」を挙げている。N P O法は立法過程で当 初「市民活動促進法」と呼ばれていたように、市民運動が発展して 法人格を取得するのはN P O法人がふさわしいというイメージがあ るのであろう。

これらとは別に、N P Oは個人で活動するよりも有利であるとい える。日本の N P O はボランティアに頼る草の根組織が多いのであ るが、それでも、積み重ねや継続性の点で組織であることが強みと なる。建築紛争を裁判所に持ち込んだ場合、都市計画法・建築基準 法上は適法な開発や施工であっても、民事的に見て、受忍限度を超 える被害が発生する場合は、金銭賠償なり計画の変更を求める和解 が勧告されるケースが多い。そのような被害を立証するには議論を 多角的に重ねる必要があるから、個人専門家よりもまちづくり N P ○のような組織のほうがやりやすい。

東京都国立市で明和地所(株)が建築した高層マンションに対し、 工事途中に市が条例で高さ制限を課した件で二つの裁判が起こされ ている。東京地裁の判決では、このマンションは建築基準法上違法 であり特定行政庁である東京都は是正す心゙きという判決と、適法で あり市はディベロッパーに賠償すべきという判決という、相反する 2 判断を示している。このように司法も摇らぐケースもあることか ら、司法の場に持ち込むさいの理論構築能力がまちづくり N P Oに
は必要となろう。

\section{おわりに一残された課題など}

都市計画や建築関係の法令・技術基準などは日進月歩であるし、特 に近年の規制緩和を受けてたびたび改正されているため、関係者は勉 強を欠かすことができない。この点で、N P Oはやや不利である。営 利企業であれば利潤の中からそうした研修などの経費を捻出すること が構造的に可能であるが、N P Oの場合、利潤を本来目的に再投資す ることは認められているとはいえ、いわゆる「儲け」は出にくいのが 宿命である。そういうハンディを負いながら、相手は一流のゼネコン であったり、法的論理構成に長けた行政庁であったりし、それらに匹 敵する知識・論理力を求められる。

また、訟争だけが紛争の解決手段ではなく、さまざまな戦略・戦術 を編み出し、クライアントを有利に導く能力も求められる。こうした ことから、建築紛争に携わるまちづくり N P Oにとっては、いかに自 己研鐁していくかが課題であるといえる。そのためには、クライアン トとなる住宅購入者あるいは近隣住民の納得をえて適正な報酬を受け 取るための理論武装と営業的努力も必要なのではないだろうか。 N P ○の欠点として「アマチュア主義または過度のプロフェッショナリズ ム」が挙げられているが23、住民などクライアントレベルのアマチュ ア主義に陥ることもなく、尃門家として過度のプロフェッショナリズ ムに固まることもないバランス感覚も求められよう。

さらにまちづくり運動論的な面では、もう一つ大きな課題がある。 それは、建築紛争は往々にして、住民ないし被害者にとって一過性の 紛争として終始し、継続的なまちづくり運動につながらないことであ る。谷中のケースで建築協定を制定する動きに結びつけたように、紛 争再発防止を目指すためには、N P.Oが個々の住民や被害者をつなぎ ネットワーク化するような機能を持つことも必要であろう。

なお、本論の主眼は建てられる側に味方するN P Oについてであっ たが、建てる側に付くN P Oというのはありえないのだろうか。理屈 からいえばありえるが、日本の狭義のＮＰＯのほとんどが市民運動の 組織化によって誕生していることを考えると、当分の間は現実的では ない。しかし、たとえば経団連も社団法人であるから広義のN P Oに 含まれるように、建設業界が紛争対応 N P O を設立することも可能性 としてはないではない。もしも、そのような組織が誕生すれば、その 時点で改めて論考の対象としたい。

\section{注}

1）12 分野とは：

(1)保陨・䧔旗または福礼:の增進

(2)社会教育的推進

(3)まちづくりの推進

(4)文化坚術またはスポーツの张與

(5)環境の保全

(6) 災洁㖨の救嗳

(7)地域安:全

(8)人権の排讙または斗利の推推

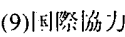

(10)多女其㴻参酒社会の形成の促進

(11) 子どもの健全辞成 
(12)こ札ら备号に揭げる活動を行う団体の连営または活動に関する逨絡・ 助豆または援助の活動

である。

なお、2002篻 12 月に法改正が行われ、2003年 5 月より以下の 5 分野が 崌加されて合部 17 分野になる。

情報化社会の発展を図る活動

科学技術の振興を図る活動

経済活動の活性化を図る活動

職業能ノの開発又は㕍用機会の㕬允を文嗳する活動 消費者の保護を図る浢動

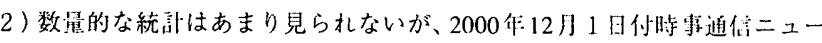
スなど。筆者も東京地裁民事第 9 部部長の須藤典明判科から耳にしてい る。

3 ）近内直人：N P O 入門、日経文庫、1999、など。

4) Johns Hopkins 大学でNPOの国際此較ブロジェクトを行っているP. Salamonによる共通定義は、最低限(1)正式に組織されていること、(2)包閣 であること、(3)利澗分配を行わないこと、(4)自己統治していること、(5)目 発的組織であること、の5 条件であり、さらに非政治・非宗教目的であ ることとしている。

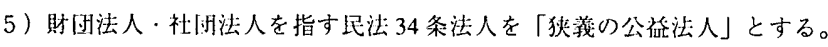
「公佮法人等」とは法人税法第 2 条拉よび別装第 2 による资茷であり、北 法 34 条法人のほ加社会福补法人・学校法人・宗教法人・这生:保灌法人、

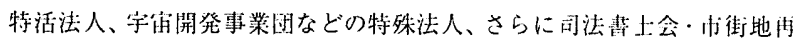
開発組合などの同業者闷体・沚業組合なども含まれている。また「公義 の公益法人」といった場合は、戌法 34 条法人に社会福祖法人・学校法人。

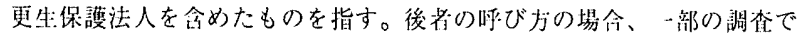

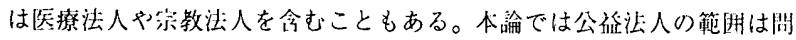
題ではないので、広義のN P Oに法人侻法でいう「公被法人管」が会ま れることのみ触れておく。

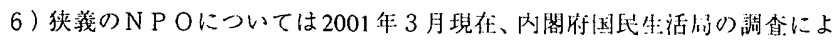

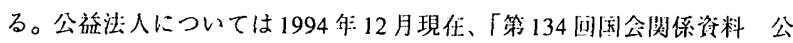
益法人等課棁成係資料」による。内訳は、比法 34 条法人 25,906 作、学校 法人 7,488件、社会福祉法人 14,502 件、宗教法人 183,897 件、その他 21,363 件、合㖕 253,156 件（N P O 法制定以前なので特做法人は存位しない）。

7 ）渡辺俊一他：用辟「まちづくり」に関する文献研究（1945～1959）、1997 年度第 32 [回 H本都市計酒学会学術研究論文集、pp.43-48、1997。

8) 都市計阿朋浯研究会編著：全訂都市訫画朋浯事典、ぎょせい、2001

9)内閣将発表掐料による。定款の表現による分類であり、補数分野にまた がるケースも少なくない。ちなみに国十交通省では「まちづくりＮＰＯ」

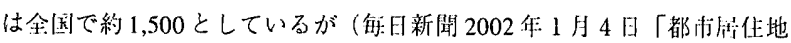

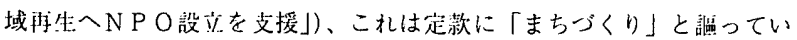

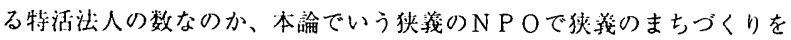
行っている団体なのかは不明である。

10）山閶義典「作まいでくり・まちづくりにおけるN P Oの役制－N P O 法 のもたらすものー」第 134 回都㠴絟営フォーラムにおける講演、1999 年: 2 月 24 H。講演内容は参照, http://wwwlk.mesh.ne.jp/toshikei/134.html。

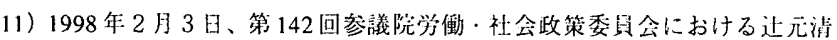
美委貴の発部。

12）紿いて「月本ボランティア学会」も設立されている。

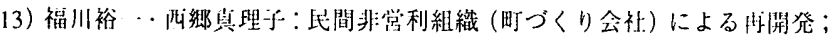

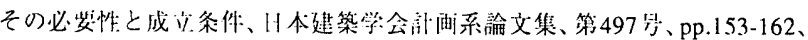
1995 。

14）建築系以外の学会でのまちの゙くりN P Oの事例塟告としては、たとえば、

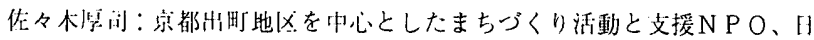
本NPO学㕕 ノンプロフィット・レビュー、第1巻1号、2001。

15）たとえば、ハウジングアンドコミュニティ財间：作いとコミュニティづく

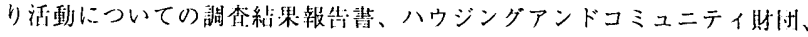
1995。

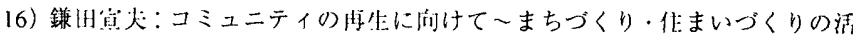

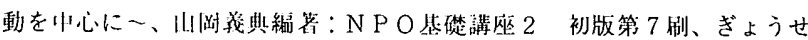
い, 2001。

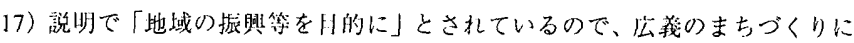
は含ま机るが狄義のまちづくりとはいいにくく、「まおおこし」に近い。

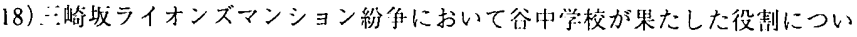

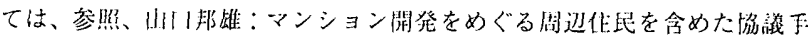

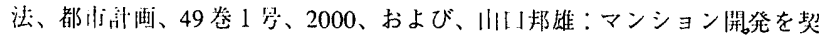
機とするまたっ゙くり、都们閔題、92卷 2 号、2001。および闹問題のホーム ページ、http://yanaka.site.ne.jp/index.html。インターネット揭示板での質問 は、 http://minken.arch.t.u-tokyo.ac.jp/arch/post3/6519.html。

19）术件の推移は、参熙、http://www.tetv.ne.jp/sakuragi/。

20）宗都の少例としては、参㫮、简明光雄：都心居作とまたづくりからみた都

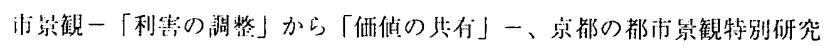

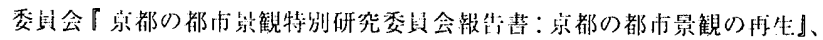
日本建築学会、2002。

21）笋者の關い合わせに対する这答。

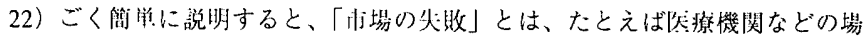

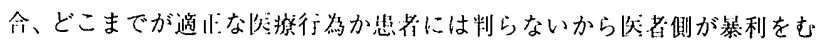
さばることが考えられるが、非営利の㹣撩機関であれば分配するはどの利

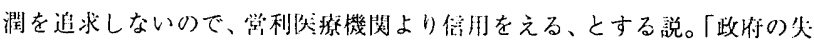

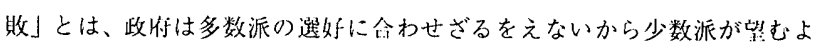
うな政策は行われないので、N P Oが必要になる、とする説。群しくは、山

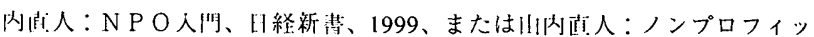
ト・エコノミー、日本呯淪社、1997。

23）浅野令与他：ジョンズ・ホプキンス人学国際比較破究プロジェクト「イン パクトアナリシス」、H本NPO学会第1 [以作次大会報售既要集、p.146、 1999。

参考文献（沫:に記截を除く）

1）NPOとまちグくり研究会：NPOとまちごくり、風古礼、1997。

2）你滕㶌編著：まちづくりの科学、毞鼠出版会、1999。

3 ）澤村明：まちづくりN P Oについてり考察、総命破究大学院大学スコープ プロジェクト・ワーキングベーパー第 4 㕺、1997。

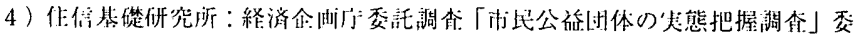

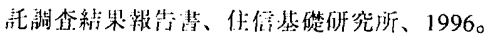

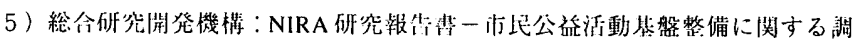

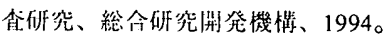

（2002年 3 月 7 日原稿受理，2002年12月 24 日採用決定） 